\title{
The Impact of Automation in Service Industries: An Empirical Study
}

\author{
M. Eva Diz-Comesaña, Nuria Rodríguez-López \\ University of Vigo, Vigo, Spain
}

\begin{abstract}
Academic research into service industries has explored the characteristics of interpersonal interactions between employees and customers, but there are few studies addressing the issues of consumer interaction with technology and its influence on the objectives and results of the operations subsystem. This study examines the elements of the service encounter, and the changes automation originates in them and their relationships. The paper also examines changes in the elements and results of the operations subsystem, as a result of automation. We propose that the customer's relationship with employees and/or technology and automated systems for the service impact the objectives and results of the operations subsystem, all of which could have an effect on the company's competitive position. The empirical study is focused on four industries, namely, toll motorways, car parks, carwash and video/DVD rental companies, in an attempt to identify objectives that lead companies to implement automated processes affecting the customer's relationship with the company. The hypotheses generated are contrasted with a structural equation modelling. The results confirm that the customer's relationship with employees and automated systems for the service impacts the objectives and results of the operations subsystem. Also, the results show how automation can enable firms simultaneously to achieve acceptable levels of flexibility and productivity, two dimensions that have traditionally been considered opposites.
\end{abstract}

Keywords: service encounter, automation, technology, operations subsystem objectives, elements of service delivery, cost, time reduction, flexibility

\section{Introduction}

Academic research into service industries has explored the characteristics of interpersonal interactions between employees and customers. A lesser number of studies address the issues of consumer interaction with technology (Dabholkar, 1996a; Bitner, Brown, \& Meuter, 2000; Anselmsson, 2001; Bowden, 2002). Much attention has been paid to the development of user profiles, the analysis of customer attitudes towards technology, and the development of customer satisfaction (see Table 1).

As self-service technologies spread, research is needed beyond the interpersonal dynamics of service encounters. Several researchers argue that technology is important for the delivery of the service (Globerson \& Maggard, 1991; Fisk, Brown, \& Bitner, 1993; Schneider \& Bowen, 1995; Dabholkar, 1996a, 1996b; Lawrence

M. Eva Diz-Comesaña, Ph.D. in Business Management, Department of Business Organization and Marketing, University of Vigo. Vigo

Nuria Rodríguez-López, Ph.D. in Business Management, Department of Business Organization and Marketing, University of

Correspondence concerning this article should be addressed to M. Eva Diz-Comesaña, Facultad de Ciencias Económicas y Empresariales, Lagoas-Marcosende s/n. Vigo, 36310, Spain. E-mail: evadiz@uvigo.es. 
\& Karr, 1996; Parasuraman, 1996; Quinn, 1996; Harvey, Lefebvre, \& Lefebvre, 1997; Meuter \& Bitner, 1998). Interactions in the traditional medium - the marketplace - give way to transactions in marketspace (Rayport \& Sviokla, 1995), and self-service technologies are the classic example.

Table 1

Main Bibliographical References

\begin{tabular}{|c|c|c|}
\hline \multicolumn{2}{|l|}{ Topics } & Main bibliographical references \\
\hline \multicolumn{2}{|c|}{ Interaction between employees and customers } & $\begin{array}{l}\text { Bowen \& Schneider, 1985; Solomon, Surprenant, Czpiel, \& Gutman, 1985; } \\
\text { Surprenant \& Solomon, 1987; Bitner, Booms, \& Tetreault, 1990; Lewis \& } \\
\text { Entwistle, 1990; Rafaeli, 1993; Mohr \& Bitner, 1995; Price, Arnould, \& } \\
\text { Deibler, 1995; Bettencourt \& Gwinner, 1996; Clemmer \& Schneider, 1996; } \\
\text { Goodwin, 1996; Goodwin \& Gremler, 1996; Hartline \& Ferrell, 1996; } \\
\text { Fischer, Gainer, \& Bristor, 1997; Gremler, Gwinner, \& Brown, 2001; Graf, } \\
\text { 2007; Specht, Fichtel, \& Meyer, 2007; Giardini \& Frese, 2008. }\end{array}$ \\
\hline \multirow{3}{*}{$\begin{array}{l}\text { Interaction } \\
\text { between } \\
\text { consumers and } \\
\text { technology }\end{array}$} & Development of user profiles & $\begin{array}{l}\text { Langeard, Bateson, Lovelock, \& Eiglier, 1981; Bateson, 1985; Zeithaml \& } \\
\text { Gilly, 1987; Darian, 1987; Greco \& Fields, 1991; Eastlick, 1996. }\end{array}$ \\
\hline & Customer attitudes & $\begin{array}{l}\text { Raub, 1981; Dabholkar, 1992, 1996a; Parasuraman, 1998; Bobbitt \& } \\
\text { Dabholkar, 2001; Dabholkar \& Bagozzi, 2002; Walker, Craig-Lees, Hecker, } \\
\text { \& Francis, 2002, Dabholkar, Bobbitt, \& Lee, 2003; Snellman \& Vihtkai, } \\
\text { 2003; Curran \& Meuter, 2005. }\end{array}$ \\
\hline & $\begin{array}{l}\text { Development of customer } \\
\text { satisfaction }\end{array}$ & $\begin{array}{l}\text { Meuter, Ostrom, Roundtree, \& Bitner, 2000; Agnihothri, Sivasubramaniam, } \\
\text { \& Simmons, 2002; Walker, Craig-Lees, Hecker, \& Francis, 2002; Pujari, } \\
\text { 2004; Ramasubbu, Mithas, \& Krishnan, 2008. }\end{array}$ \\
\hline
\end{tabular}

With these developments in mind, we propose to examine the customer's relationship with employees and/or technology, and the impact of automated systems for the service on the objectives and results of the operations subsystem, all of which could have an effect on the company's competitive position. The information we employed was mainly acquired by means of a postal survey, directed to a sample of companies in the following subsectors: toll motorways, carparks, carwash services, and video/DVD rental. The companies in the sample had gross sales of at least 300,506.05€ in 2009, and were located in Spain in the year of reference for the research.

The paper is divided into four sections. The first part is the introduction part. Section two sets out the purpose of the research, defines the variables to study and proposes hypotheses. The main points and the findings of the statistical analysis are examined in section three. Finally, the main conclusions are developed from the findings of the research.

\section{Purpose and Design of the Research}

The purpose of this research is to analyse possible relationships between the degree of automation and the objectives, elements, and results of the operations subsystem, with emphasis on external automation, that is, the automation processes which affect the customer's relationship with the company. Thus, our interest centres on studying the following questions (see Figure 1):

- To what extent do the objectives of the operations subsystem originate the implementation of external automation processes? On a secondary level, we analyse whether automation originates the implementation of certain objectives.

- What changes does external automation originate in the elements of the subsystem?

- How do the results of the subsystem develop, as a consequence of external automation?

On a secondary level, we also attempt to analyse the possible relationship between how an objective is 
fixed and how the results for the objective develop.

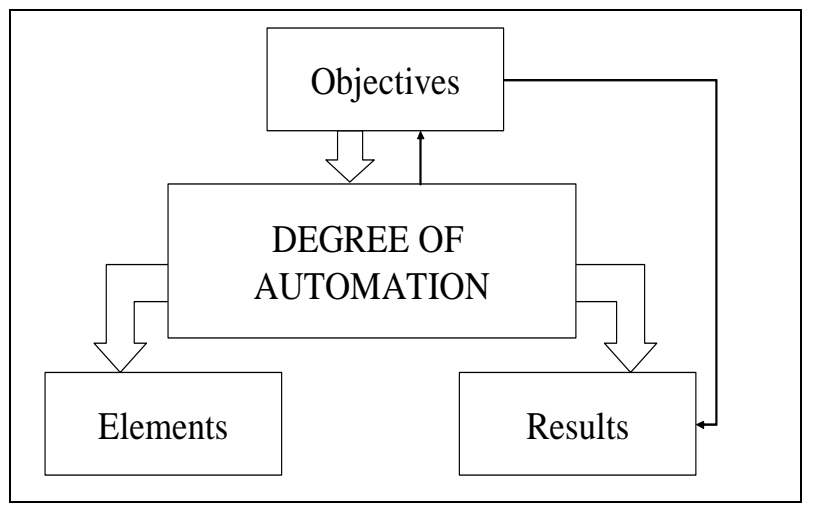

Figure 1. Model under analysis.

\section{Variables Considered in the Research}

The variables we intend to study can be divided into four groups: degree of automation, elements with a role in rendering the service, and objectives and results of the operations subsystem.

Degree of automation. The purpose of this variable is to reflect the degree of automation of the company. To this end, we established different levels according to the characteristics of the technology employed. We obtained these data by means of conversations with the main companies and technology suppliers in the subsectors under analysis. The levels were established according to the time and the country where the research was carried out.

The elements of service delivery. Most services are the result of processes which are mostly carried out in direct contact between customers and the company's frontline employees, in what Normann (1984) called "the moment of truth". A service encounter generally takes place on-site at the company which provides the service, and includes three inter-acting elements: the customer, front-line employees, and the organisation (Bateson, 1985; Solomon, Surprenant, Czpiel, \& Gutman, 1985). Each of these elements has its own priorities and objectives and these can conflict in ways which are sometimes difficult to solve ${ }^{1}$.

The organisation establishes the physical and cultural environment for the service encounter. Employees have a certain degree of independence, because the company culture instils a set of values which condition employee behaviour to some extent, reducing the need for direct supervision. However, company culture alone does not ensure successful decision taking from employees. Employees need to be informed, motivated, trained, and competent for carrying out their functions ${ }^{2}$.

Service encounters can take different forms, as Chase, Aquilano, and Jacobs (1998) showed in their service-system design matrix (see Figure 2).

The upper part of the matrix charts the degree of contact between the customer and frontline employees. When no contact occurs, a buffered core is physically separated from the customer. A permeable system appears when the customer can establish contact by telephone or by physical presence. Finally, when the system is permeable and reacts to customer demands, the system is called reactive.

\footnotetext{
1 Parasuraman (1996) analyses the relation between technology and the elements of the service encounter. Agnihothri, Sivasubramaniam, and Simmons (2002) examine the impact of technology on the relations between the elements.

2 The role of information technologies is important to enable companies to give employees sufficient information (Schlessinger \& Heskett, 1991), and support for their relationships with customers (Mulligan \& Gordon, 2002).
} 


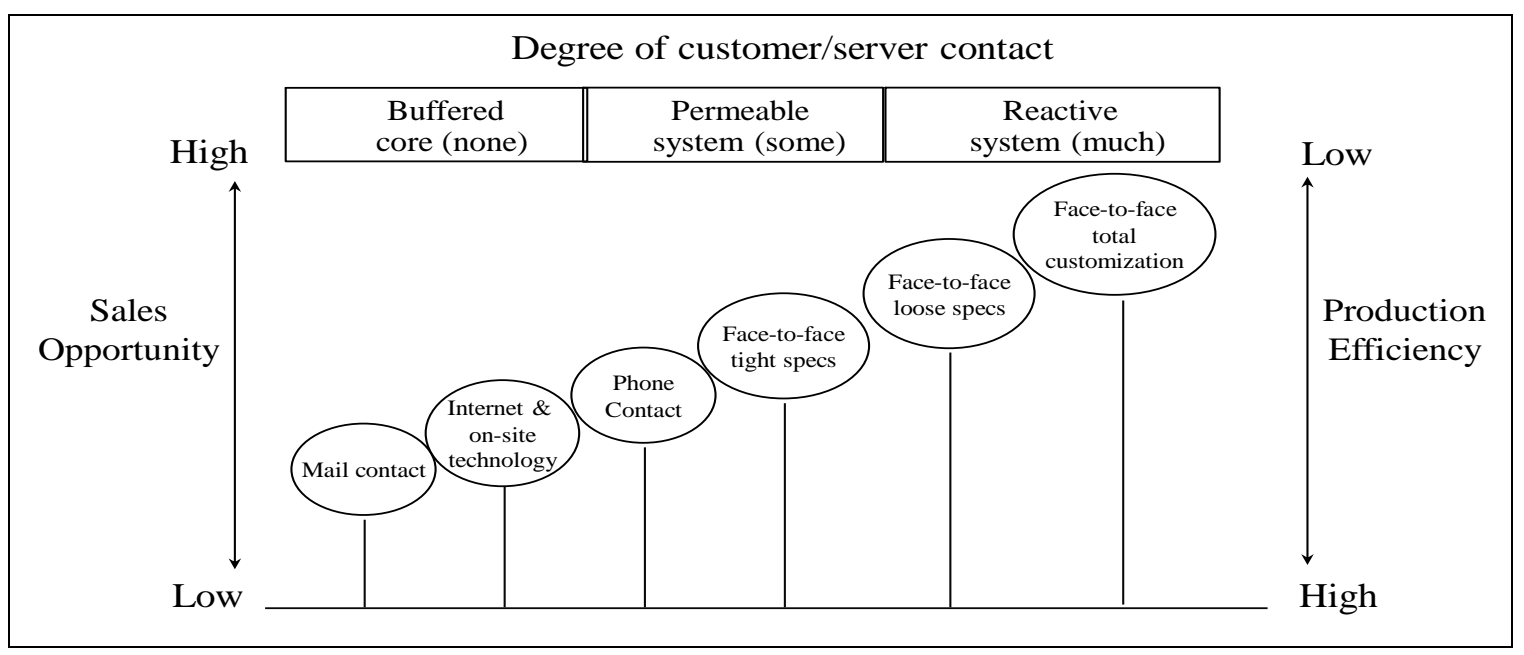

Figure 2. Service-system design matrix (Chase, Aquilano, \& Jacobs, 1998).

The left side of the matrix reflects a logical marketing proposition. Increased contact means increased opportunity for sales, and vice versa.

The right side shows the effect of customer influence on production efficiency. Increased customer contact with the system causes reduced production efficiency, and vice versa.

The matrix entries show the different ways that the service can be provided. Mail order is at one end of the matrix, and, at the other end, we find face-to-face contact and customisation by adapting products to customer demand (e.g., medical services). In between are on-site technology (e.g., vending machines), telephone contact and face-to-face contact, either with tight specifications (e.g., fast-food restaurants), or with loose specifications (e.g., conventional restaurants).

After analysing the relationship between customers and suppliers, we examined the impact of other customers on the service encounter. Other customers can have a significant influence if customers are physically together in the same place, and interact with the other factors, which take part in production (Martin \& Pranter, 1989; Grove \& Fisk, 1997). In fact, Eiglier and Langeard (1991) suggested that several factors interact in the service industry operations system — what they call the servuction system. Three factors belong to the company: frontline employees, physical support, and the internal organisation system. A further two factors belong to the market: the customer and other customers. The service is the final factor and results from interaction between customers and company factors.

For each of these elements, the factors we analysed originated from the following variables (see Table 2).

Objectives of the operations subsystem. Economic success and company survival are the result of establishing objectives that satisfy the market's needs and wishes. Establishing objectives in this way will determine the limits and the focus of an organisation, and make it easier to develop good strategy.

Once the company has fixed on its general objectives, each functional area will determine theirs. Thus, Skinner (1969) initially admit four competitive priorities, which are the base for establishing generic production strategies: cost, quality, delivery time, and flexibility. Garvin $(1988,1994)$ and Leong, Senyder, and Ward (1990) identify the following objectives: quality, delivery, cost, flexibility, and innovation. Slack, Cambers, Johnston, Harland, and Harrison (1994) identify the following as measures of performance: cost, quality, flexibility, safety, and time. 
Table 2

Operations Subsystems Variables

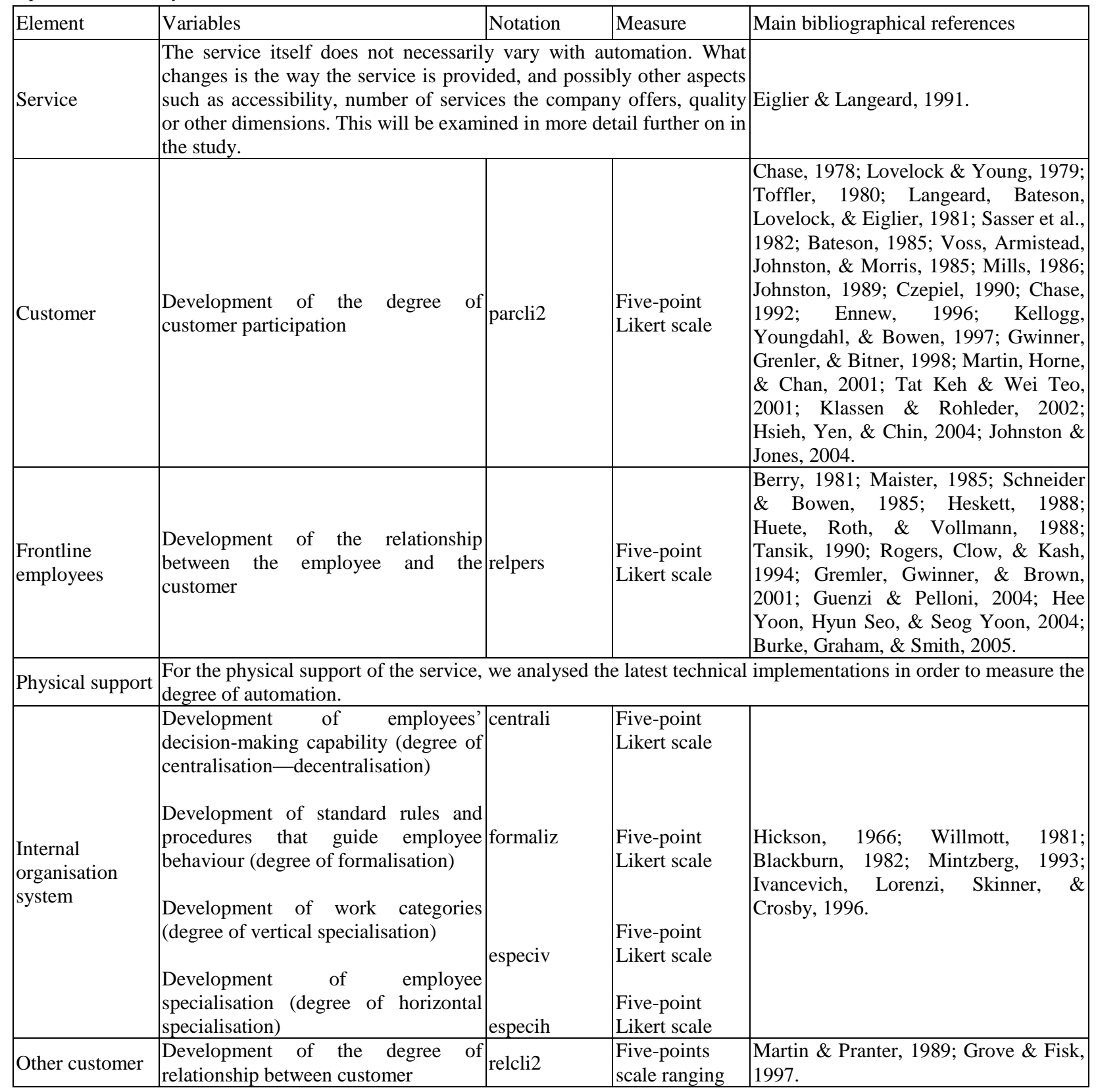

In the past few years, several researchers (Gupta, 1995; Gupta \& Sharma, 1996; Newman \& Hanna, 1996; Angel \& Klassen, 1999; De Burgos, 1999) have recognised the importance of the environment as a new competitive priority. Thus, today we can identify six objectives: cost, quality, time, flexibility, customer service, and environment. However, the present paper will only research the first five (see Table 3).

Results of the operations subsystem. To analyse the evolution of results for the operations subsystem, we analysed the same points as came under examination for objectives, i.e., costs, time, quality, time, flexibility, and customer service. The following variables were employed (see Table 4). 
Table 3

Variables Which Relate to the Operations Subsystem Objectives

\begin{tabular}{|l|l|l|l|}
\hline Objective & Variable & Notation & Variable measurement \\
\hline Costs & Importance of the costs objective & ocostes & Five-point Likert scale \\
\hline Quality & Importance of the quality objective & ocalidad & Five-point Likert scale \\
\hline Time & Importance of the time objective & otiempo & Five-point Likert scale \\
\hline Flexibility & Importance of the flexibility objetive & oflexib & Five-point Likert scale \\
\hline Customer service & Importance of the customer service objective & oserv & Five-point Likert scale \\
\hline
\end{tabular}

Table 4

Variables Related to the Operations Subsystem Results

\begin{tabular}{|c|c|c|c|c|}
\hline Result & Variable & Notation & Measure & Main bibliographical references \\
\hline Costs & $\begin{array}{l}\text { For costs, we analysed investment in automation } \\
\text { and the change in the number of employees in the } \\
\text { company. Costs were initially used as a latent } \\
\text { variable but failed to fulfil criteria for reliability }{ }^{3} \text {. } \\
\text { After analysing several options, we considered } \\
\text { that the most appropriate alternative is to create a } \\
\text { variable defined as the quotient between the } \\
\text { amount invested and the change in the number of } \\
\text { employees. }\end{array}$ & invemp2 & Metric variable & $\begin{array}{l}\text { Shaw \& Capoor, 1979; Lewis \& } \\
\text { Chambers, 1997; Buggie, } 1998 .\end{array}$ \\
\hline Quality & $\begin{array}{l}\text { Behaviour of the number of quality complaints } \\
\text { from customers }\end{array}$ & rcalid2 & $\begin{array}{l}\text { Five-point Likert } \\
\text { scale }\end{array}$ & $\begin{array}{l}\text { Cadotte \& Turgeon, 1988; Johnston, } \\
\text { 1995; Friman, Edvardsson, \& Gärling, } \\
\text { 2001; Friman \& Gärling, 2001; } \\
\text { Friman \& Edvardsson, 2003, Chen, } \\
\text { Lin, \& Kinshuk, 2004. }\end{array}$ \\
\hline Time & Development of changes in waiting times & rtiempo 2 & $\begin{array}{l}\text { Five-point Likert } \\
\text { scale }\end{array}$ & $\begin{array}{l}\text { Fessard, 1993; Miller \& Roth, 1994; } \\
\text { Kim \& Arnold, 1996; Ward, } \\
\text { McCreery, Ritzman, \& Sharma, 1998; } \\
\text { Boyer \& McDermott, } 1999 .\end{array}$ \\
\hline Flexibility & $\begin{array}{l}\text { Respecto a la flexibilidad se han analizado dos } \\
\text { aspectos: } \\
\text { Development of service accessibility } \\
\begin{array}{l}\text { Development of the number of services offered } \\
\text { by the company }\end{array}\end{array}$ & acceserv & $\begin{array}{l}\text { Five-point Likert } \\
\text { scale } \\
\text { Metric variable }\end{array}$ & $\begin{array}{l}\text { Gerwin, 1987; Cox, 1989; Miller \& } \\
\text { Roth, 1994; Kim \& Arnold, 1996; } \\
\text { Ward et al., 1998; Harvey, Lefebvre, } \\
\& \quad \text { Lefebvre, 1997; Boyer \& } \\
\text { Mcdermott, 1999. }\end{array}$ \\
\hline $\begin{array}{l}\text { Customer } \\
\text { service }\end{array}$ & 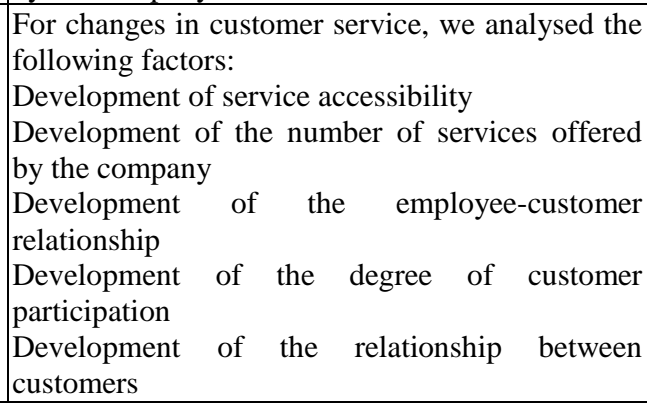 & $\begin{array}{l}\text { acceserv } \\
\text { nser } \\
\text { parcli2 } \\
\text { relpers } \\
\text { relcli2 }\end{array}$ & \begin{tabular}{|l|} 
Five-point Likert \\
scale \\
Metric variable \\
Five-point Likert \\
scale \\
Five-point Likert \\
scale \\
Five-point Likert \\
scale
\end{tabular} & See previous square, and Table 2. \\
\hline
\end{tabular}

\section{Research Propositions}

Once the variables had been defined, we formulated four types of hypotheses (see Figure 3). To do this, we employed a model which was wholly made up by observable variables. Each of the hypothesis types corresponds to one of the research objectives, which were specified at the beginning of the second chapter.

\footnotetext{
${ }^{3}$ Aleatory error, which appears when scale measurements are not stable and consistent.
} 


\section{Type 1 Propositions}

Objective: Cost reduction (P1a)

Objective: Time reduction $(\mathrm{P} 1 \mathrm{~b})$

Objective: Improved quality (P1c)

Objective: Improved flexibility (P1d)

Objective: Improved customer service (P1e)

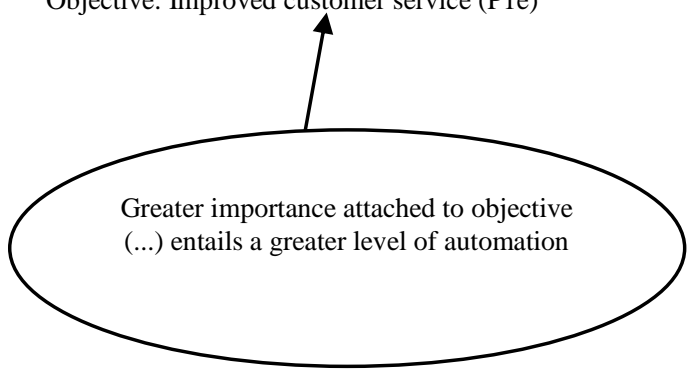

Type 4 Propositions

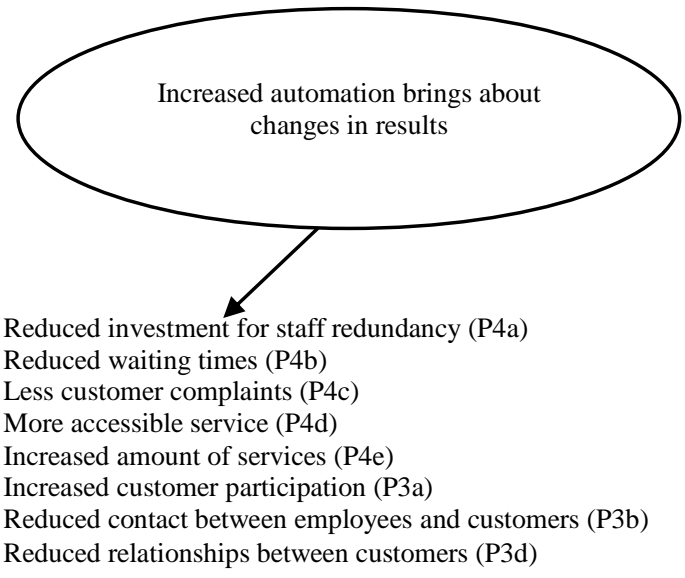

\section{Type 3 Propositions}

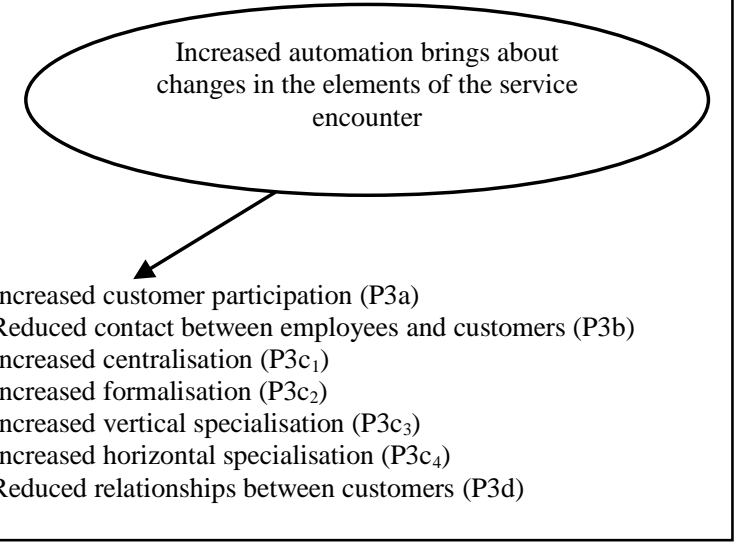

\section{Type 5 Propositions}

Objective: Cost reduction Objective: Time reduction Objective: Improved quality Objective: Improved flexibility Objective: Improved customer service (H1e)

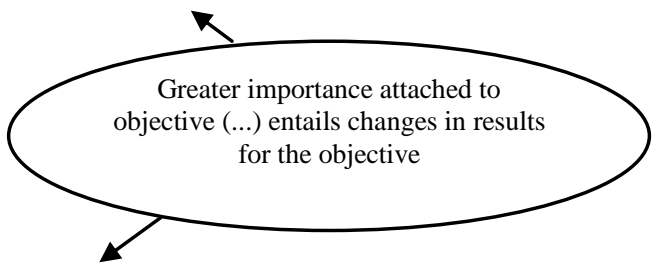

Reduced investment for staff redundancy (P5a)

Reduced waiting times (P5b)

Less customer complaints (P5c)

More accessible service (P5d)

Increased amount of services (P5e)

More accessible service (P5f)

Increased amount of services (P5g)

Increased customer participation (P5h)

Reduced contact between employees and

customers (P5i)

Reduced relationships between customers (P5j)

Figure 3. Research propositions.

\section{Research Method}

\section{Obtaining Data}

The sample we researched comprises Spanish companies in the following subsectors: toll motorways, carparks, carwash services, and video/DVD rental ${ }^{4}$. The companies had gross sales of at least 300,506.05€ in 2009. The size of the population was 202 companies, comprising 10 companies (4.95\%) from the toll motorway industry, 112 car parks (55.44\%), 49 carwash companies (24.26\%), and 31 video and DVD rental firms $(15.35 \%)$.

Out of the 202 companies which comprise the total population, we selected 99 for survey, by stratified random sampling, with a $5 \%$ margin of error and a confidence level of $95 \%$. Information was collected by

\footnotetext{
${ }^{4}$ SIC codes 4784, 7523, 7525, 7542, and 7823.
} 
postal and telephone survey, between March and June 2010.

Twenty-three out of the 99 companies surveyed said they had not recently undergone any automation processes affecting customer relationships. The main reason was that they considered that their processes were sufficiently automated. The second reason was that there is no customer demand for further automation.

The remaining 76 companies $(5.2 \%$ from the toll motorway industry, $55.3 \%$ car parks, $23.7 \%$ carwash companies, and $15.8 \%$ video and DVD rental firms) said they had undergone such automation processes recently. The most frequently mentioned causes, in order of importance, were the appearance of new technologies, the need to keep up with competition, and customer requirements. The main point of interest of this research lies in customer requirements.

\section{Statistical Analysis}

The choice of the statistical technique to use in research depends on the objectives of the research. The present paper intends to contrast the propositions jointly (as a model), bearing in mind that some variables are simultaneously exogenous and endogenous, according to the variable they relate to. For this reason, the chosen procedure was structural equations analysis. The research propositions gave rise to the following causal relationships within variables:

$$
\begin{aligned}
& \text { gautom } 2=\gamma_{11} \text { ocostes }+\gamma_{12} \text { otiempo }+\gamma_{13} \text { ocalidad }+\gamma_{14} \text { oflexib }+\gamma_{15} \text { oserv }+\zeta_{1} \\
& \text { parcli } 2=\gamma_{25} \text { oserv }+\beta_{21} \text { gautom } 2+\zeta_{2} \\
& \text { relpers }=\gamma_{35} \text { oserv }+\beta_{31} \text { gautom } 2+\zeta_{3} \\
& \text { centrali }=\beta_{41} \text { gautom } 2+\zeta_{4} \\
& \text { formaliz }=\beta_{51} \text { gautom } 2+\zeta_{5} \\
& \text { especiv }=\beta_{61} \text { gautom } 2+\zeta_{6} \\
& \text { especih }=\beta_{71} \text { gautom } 2+\zeta_{7} \\
& \text { relcli } 2=\gamma_{85} \text { oserv }+\beta_{81} \text { gautom } 2+\zeta_{8} \\
& \text { invemp } 2=\gamma_{91} \text { ocostes }+\beta_{91} \text { gautom } 2+\zeta_{9} \\
& \text { rtiempo } 2=\gamma_{102} \text { otiempo }+\beta_{101} \text { gautom } 2+\zeta_{10} \\
& \text { rcalid } 2=\gamma_{113} \text { ocalidad }+\beta_{111} \text { gautom } 2+\zeta_{11} \\
& \text { acceserv }=\gamma_{124} \text { oflexib }+\gamma_{125} \text { oserv }+\beta_{12} \text { gautom } 2+\zeta_{12} \\
& \text { nser }=\gamma_{134} \text { oflexib }+\gamma_{135} \text { oserv }+\beta_{131} \text { gautom } 2+\zeta_{13}
\end{aligned}
$$

The present paper is part of wider research employing several exploratory tools. Therefore, we used a structural equations model based on covariance analysis, to enhance the confirmatory character of the research. For estimation, although the variables, after some transformation, appeared moderately normal, we resampled by means of a bootstrapping technique. The model which arose from the research propositions was re-specified to achieve acceptable fit. The structural equations were defined as follows:

$$
\begin{aligned}
& \text { parcli } 2=\gamma_{26} \text { gautom } 2+\beta_{23} \text { relpers }+\zeta_{2} \\
& \text { relpers }=\gamma_{36} \text { gautom } 2+\beta_{313} \text { nser }+\zeta_{3} \\
& \text { relcli } 2=\gamma_{86} \text { gautom } 2+\beta_{810} \text { rtiempo } 2+\beta_{812} \text { acceserv }+\zeta_{8} \\
& \text { invemp } 2=\gamma_{91} \text { ocostes }+\gamma_{96} \text { gautom } 2+\zeta_{9} \\
& \text { rtiempo } 2=\gamma_{102} \text { otiempo }+\gamma_{106} \text { gautom } 2+\beta_{103} \text { relpers }+\zeta_{10} \\
& \text { rcalid } 2=\gamma_{113} \text { ocalidad }+\zeta_{11} \\
& \text { acceserv }=\gamma_{124} \text { oflexib }+\gamma_{12} \text { oserv }+\gamma_{126} \text { gautom } 2+\beta_{122} \text { parcli } 2+\zeta_{12}
\end{aligned}
$$


nser $=\gamma_{134}$ oflexib $+\zeta_{13}$

Tables 5-7 show goodness of fit indices for the initial model and the model after re-specification ${ }^{5}$.

Table 5

Absolute Adjustment

\begin{tabular}{lll}
\hline Absolute adjustment & Initial model & Final model \\
\hline Degrees of freedom & 116 & 58 \\
Chi-square ( $p$-value) & $173.520(0.000)$ & $59.021(0.501)$ \\
Goodness of Fit Index (GFI) & 0.711 & 0.894 \\
Relative Goodness of Fit Index (RGFI) & 0.832 & 0.991 \\
Root Mean Square Error of Approximation (RMSEA) & 0.083 & 0.067 \\
Noncentrality Parameter (NCP) & 57.520 & 1.021 \\
McDonald's transformation (MDN) & 0.685 & 0.993 \\
Excepted Cross-Validation Index (ECVI) & 3.780 & 2.040 \\
\hline
\end{tabular}

Table 6

Incremental adjustment

\begin{tabular}{lll}
\hline Incremental adjustment & Initial model & Final model \\
\hline Adjusted Goodness of Fit Index (AGFI) & 0.574 & 0.808 \\
Relative Adjusted Goodness of Fit Index (RAGFI) & 0.730 & 0.983 \\
Normed Fit Index (NFI) & 0.700 & 0.876 \\
Tucker Lewis Index (TLI) & 0.822 & 0.996 \\
Incremental Fit Index (IFI) & 0.876 & 0.998 \\
Relative Fit Index (RFI) & 0.604 & 0.805 \\
Comparative Fit Index (RFI) & 0.865 & 0.997 \\
\hline
\end{tabular}

Table 7

Parsimony Adjustment

\begin{tabular}{lcc}
\hline Parsimony adjustment & Initial model & Final model \\
\hline Akaike Information Criterion (AIC) & 283.520 & 153.021 \\
Parsimonious Normed Fit Index (PNFI) & 0.531 & 0.558 \\
Parsimonious Goodness of Fix Index (PGFI) & 0.482 & 0.494 \\
Normed Ji-Square & 1.496 & 1.018 \\
\hline
\end{tabular}

Relationships between variables are considered significant for $\mid t$-value $\mid>1.96(\alpha=0.05)$ (see Table 8).

Table 8

Values and Level of Significance for Structural Coefficients in the Final Model

\begin{tabular}{llll}
\hline & Causal relationships & Standardised structural coefficients & $t$-value $(\alpha=0.05)$ \\
\hline$\gamma_{26}$ & parcli2 $\leftarrow$ gautom2 & -0.280 & -2.981 \\
$\gamma_{36}$ & relpers $\leftarrow$ gautom2 & -0.899 & -7.935 \\
$\gamma_{86}$ & relcli2 $\leftarrow$ gautom2 & 0.351 & 6.086 \\
$\gamma_{96}$ & invemp2 $\leftarrow$ gautom2 & 0.185 & $1.958^{*}$ \\
\hline
\end{tabular}

\footnotetext{
5 All the indices show good adjustment, except GFI, with acceptable adjustment, and AGFI, NFI, and RFI, which are close under the limit. This is because the size of the sample and the amount of indicators affect the indices. Other measurements were used to correct this. Incremental indices TLI, IFI, and CFI do not have these problems and show good adjustment. Relative Goodness of Fit Index (RGFI), which should take values over 0.9, obtains a value of 0.991 for the respecified model. For Relative Adjusted Goodness of Fit Index (RAGFI), 0.8 is the limit for accepting the model, and the final model shows a value of 0.983 .
} 
(Table 8 continued)

\begin{tabular}{llcc}
\hline & Causal relationships & Standardised structural coefficients & $t$-value $(\alpha=0.05)$ \\
\hline$\gamma_{106}$ & rtiempo $\leftarrow$ gautom 2 & 0.234 & 3.196 \\
$\gamma_{126}$ & acceserv $\leftarrow$ gautom2 & 0.341 & 3.938 \\
$\gamma_{91}$ & invemp $\leftarrow$ ocostes & 0.520 & 5.027 \\
$\gamma_{102}$ & rtiempo $\leftarrow$ otiempo & 0.330 & 2.254 \\
$\gamma_{113}$ & rcalid2 $\leftarrow$ ocalidad & 0.301 & 2.508 \\
$\gamma_{124}$ & acceserv $\leftarrow$ oflexib & 0.237 & 1.996 \\
$\gamma_{134}$ & nser $\leftarrow$ oflexib & 0.292 & 2.509 \\
$\gamma_{125}$ & acceserv $\leftarrow$ oserv & 0.229 & $1.921^{*}$ \\
$\beta_{23}$ & parcli2 $\leftarrow$ relpers & 0.339 & 1.999 \\
$\beta_{103}$ & rtiempo $\leftarrow$ relpers & -0.341 & -3.395 \\
$\beta_{812}$ & relcli2 $\leftarrow$ acceserv & 0.158 & 2.601 \\
$\beta_{810}$ & relcli2 $\leftarrow$ rtiempo2 & 0.236 & 3.875 \\
$\beta_{313}$ & relpers $\leftarrow$ nser & 0.466 & 3.171 \\
$\beta_{122}$ & acceserv $\leftarrow$ parcli2 & -0.304 & -2.502 \\
\hline
\end{tabular}

Notes. ${ }^{*}$ Considered significant, for $\alpha=0.05$, because of its closeness to 1.96 . The minus signs comes from the way that the variables are defined.

Reliability was excellent for all the structural equations except for those expressing changes in the amount of customer complaints and amount of services. These show lower squared multiple correlations (SMCs) (see Table 9).

Table 9

Representativity of Structural Equations in the Final Model

\begin{tabular}{ll}
\hline Structural equations & SMCs \\
\hline Relpers & 0.951 \\
relcli2 & 0.934 \\
parcli2 & 0.523 \\
Invemp2 & 0.619 \\
rtiempo2 & 0.674 \\
rcalid2 & 0.384 \\
Acceserv & 0.638 \\
Nser & 0.298 \\
\hline
\end{tabular}

\section{Conclusions}

The re-specified model shows that some of the initial causal relationships did not prove significant. The Type 1 propositions, which related operations subsystem objectives to the degree of automation, were rejected and removed from the model. Type 2 propositions were introduced, as defined in Figure 4.

These relationships were not significant. In the final model, the objectives and the degree of automation were reflected as independent variables, with co-relations established between them.

We also analysed the importance of the operations subsystem objectives which automation attempts to achieve. Improved customer service was shown to be the most important, followed by time reduction, cost reduction, improved flexibility, and improved quality.

Regarding the relationship between the degree of automation and the elements of the operations subsystem (Type 3 hypotheses) several causal relationships appeared. An increased degree of automation means a greater 
degree of customer participation (proposition 3a), reduced relationships between employees and customers (proposition 3b) and reduced levels of relationships between customers. These results are to be expected when an automated system takes the place of a non-automated system. An increase in the degree of automation should not necessarily bring about these results, but the company has this perception because the non-automated system is less used by the customer.

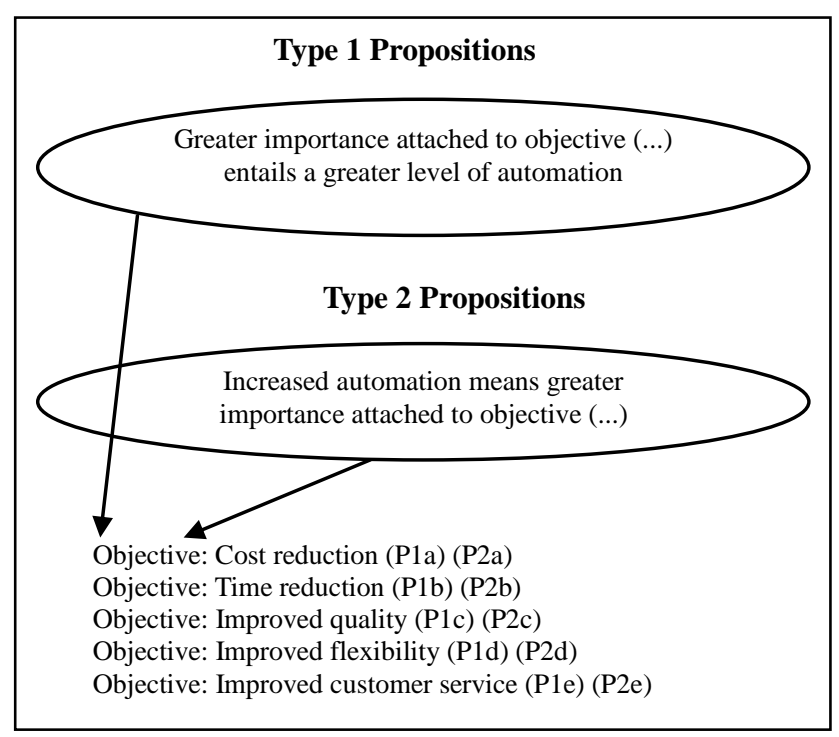

Figure 4. Type 1 and Type 2 propositions.

These results are favourable towards implementation of automated systems, especially in activities which do not require a large amount of work from frontline employees, as in car parks or toll motorways. Automation is also a plus for services where customers require privacy and minimum contact with employees or other customers, as in film rental.

Automation means the customer must undertake tasks which are carried out by frontline employees in non-automated systems. Two different reactions may ensue. Customers may feel annoyed by having to take a more active role, or they may feel personally enhanced by their new tasks. Automation does not usually mean a great effort for customers, but automation may mean a change in customers' perceived level of risk, as, in an automated system, although the customer has a greater intervention in the production of the service, facing a machine instead of a person may enhance the feeling of risk, even though there is often actually less risk.

As regards the propositions about the system of internal organisation, automation does not appear to have a significant influence on the degree of centralisation, formalisation, vertical or horizontal specialisation, and this remains stable in most cases. The results are conditioned by the fact that, in many companies, the implementation of automated systems does not mean suppressing traditional systems. Both are employed simultaneously.

Propositions about the relationship between automation and results (Type 4 propositions) suggest that a greater degree of automation means reduction in the quotient between investment for automation and changes in staff numbers, reduced waiting times, and increased accesibility for the service.

No significant relationship appears present between the degree of automation and the evolution of the number of customer complaints. Neither is a significant relationship apparent between degree of automation and number of services. The number of services remains constant in most cases and appears independent from the degree of automation. 
Type 5 propositions, which relate objectives to results, suggest that when greater importance is attached to an objective, better results are obtained for the objective. However, for the "customer service improvement" objective, no significant relationship appears between the importance attached to the objective and the development of the amount of services which are provided. A causal relationship is established between the degree of importance of the objective and the degree of accessibility to the service - which the customer values positively (proposition 5f). This needs to be borne in mind, as customer opinion is positive for increases in the amount of services delivered, but negative when the number of services is reduced. However, if we change the level of significance to 0.1 from 0.05 , the proposition is not rejected.

The propositions which relate the importance attached to the customer service improvement objective to the development of customer participation (proposition 5h) and customer relationships with frontline employees (proposition 5i) were rejected. This was to be expected in a context where automation is intended to achieve an improvement in customer service. The changes towards reduced personal contact between employees and customers and the customer's more active role in the provision of the service do not have a negative perception for the customer, and are valued as indifferent.

Hypothesis $5 \mathrm{j}$, which relates the degree of importance of the customer service improvement objective to the evolution of the degree of relationship between customers, is also rejected. We must say that less relationship between customers is not necessarily positive from the customer point of view. The average opinion is faintly positive, and very close to indifference.

A set of causal relationships are introduced to improve the consistency of the model. Reduced relationships between employees and customers compel customers to increase their participation in the delivery of the service. The reduced customer-employee relationship allows a reduction in waiting times.

Enhanced accessibility for the service implies reduced customer-to-customer relationships, as customers have longer hours for using the service, and can obtain service at an increased number of sales points (meaning units - persons or machines - where the customer can obtain the service). Reduced waiting time further reduces customer-to-customer relationships, as customers spend less time on company premises for relationships with other customers to take place.

We suggest that when the number of services is increased, a greater employee-customer relationship is also required, as automated processes may not be practical for very large numbers of services. The amount of services is only reduced when the pre-automation system is not maintained, and this would appear to indicate that reducing the number of services is not an objective of the process, but a necessary consequence of the suppression of the previous system.

Finally, increased customer participation means increased accessibility for the service, as customer participation often allows a greater number of sales points and wider service timetables.

To sum up, our empirical study suggests that the implementation of automated systems in service companies simultaneously achieves acceptable levels of productivity and flexibility. Efficiency and flexibility have traditionally been understood to be antagonistic competitive objectives, and these results suggest that service automation can make the two more compatible.

\section{References}

Agnihothri, S., Sivasubramaniam, N., \& Simmons, D. (2002). Leveraging technology to improve field service. International Journal of Service Industry Management, 13(1), 47-68. 
Angell, L. C., \& Klassen, R. O. (1999). Integrating environmental issues into the mainstream: An agenda for research in operations management. Journal of Operations Management, 17(5), 575-598.

Anselmsson, J. (2001). Customer-perceived service quality and technology-based self-service. Lund: Lund Business Press.

Avkiran, N. K. (1999). Quality customer service demands human contact. International Journal of Bank Marketing, 17(2), 61-74.

Bateson, J. E. (1985). Perceived control and the service encounter. In J. A. Czpiel, M. R. Solomon, \& C. F. Surprenant (Eds.), The Service Encounter. Lexington, M.A.: Lexington Books.

Berry, L. L. (1981). The employee as customer. Journal of Retail Banking, 3(1), 33-40.

Bettencourt, L., \& Gwinner, K. (1996). Customization of the service experience: The role of the frontline employee. International Journal in Service Industry Management, 7(2), 2-20.

Bitner, M. J., Booms, B. H., \& Tetreault, M. S. (1990). The service encounter: Diagnosing favorable and unfavorable incidents. Journal of Marketing, 54(1), 71-84.

Bitner, M. J., Brown, S. W., \& Meuter, M. L. (2000). Technology infusion in service encounters. Journal of the Academy of Marketing Science, 28(1), 138-149.

Blackburn. (1982). Dimensions of structure: A review and reappraisal. Academy of Management of Review, 1, 59-66.

Bobitt, L. M., \& Dabholkar, P. A. (2001). Integrating attitudinal theories to understand and predict use of technology-based self-service: The Internet as an illustration. International Journal of Service Industry Management, 12(5), 423-450.

Bowden, B. (2002). Customers help check out new technology. Arkansas Business, 19(5), 15-18.

Bowen, D. E., \& Schneider, B. (1985). Boundary spanning role employees and the service encounter: Some guidelines for management research. In J. A. Czpiel, M. R. Solomon, \& C. F. Surprenant (Eds.), The service encounter. Lexington, M.A.: Lexington Books.

Boyer, K. K., \& McDermott, C. H. (1999). Strategic consensus in operations strategy. Journal of Operations Management, 17, 289-305.

Buggie, F. D. (1998). We want to know about productivity (Queremos saber de productividad). Harvard-Deusto Business Review, 82, 90-94.

Burke, R. J., Graham, J., \& Smith, F. (2005). Effects of reengineering on the employee satisfaction-customer satisfaction relationship. The TQM Magazine, 17(4), 358-363.

Cadotte, E. R., \& Turgeon, N. (1988). Dissatisfiers and satisfiers: Suggestions for consumer complaints and compliments. Journal of Consumer Satisfaction, Dissatisfaction and Complaining Behavior, 1, 74-79.

Chase, R. B. (1978). Where does the customer fit in a operations? Harvard Business Review, 56(6), 137-142.

Chase, R. B. (1992). The customer contact approach to services: Theoretical bases and practical extensions. In C. H. Lovelock (Ed.), Managing services: Marketing, operations, and human resources (pp. 43-49). United States: Prentice-Hall.

Chase, R. B., Aquilano, N. J., \& Jacobs, F. R. (1998). Production and operations management: Manufacturing and services. Boston: Irwin McGraw-Hill.

Chen, N. S., Lin, K. M., \& Kinshuk (2004). Assessment of e-learning satisfaction from critical incidents perspective. Proceedings of 6th International Conference on Enterprise Information Systems (pp. 27-34). Porto-Portugal.

Clemmer, E. C., \& Schneider, B. (1996). Fair service. In T. A. Swartz, D. E. Bowen, \& S. W. Brown (Eds.), Advances in services marketing and management (pp. 109-126). Greenwich, C.T.: JAI Press.

Cox, T. (1989). Toward the measurement of manufacturing flexibility. Production and Inventory Management Journal, 30(1), 68-72.

Curran, J. M., \& Meuter, M. L. (2005). Self-service technology adoption: Comparing three technologies. Journal of Service Marketing, 19(2), 103-113.

Czepiel, J. A. (1990). Relationships with customer: A differentiating philosophy of marketing. In D. E. Bowen, R. B. Chase, \& T. G. Cummings (Eds.), Service management effectiveness: Balansing strategy, organization and human resources, operations, and marketing (pp. 299-323). United States: Jossey-Bass Publishers.

Dabholkar, P. A. (1992). Role of affect and need for interaction in on-site service encounters. In J. F. Sherry, \& B. Sternthal (Eds.), Advances in consumer research (pp. 563-569). Provo: Association for Consumer Research.

Dabholkar, P. A. (1996a). Consumer evaluations of new technology-based self-service options: An investigation of alternative models of service quality. International Journal of Research in Marketing, 13(1), 29-51.

Dabholkar, P. A. (1996b). Technology-based service delivery: A classification scheme for developing marketing strategies. In T. A. Swartz, D. E. Bowen, \& S. W. Brown (Eds.), Advances in services marketing and management (pp. 241-71). Greenwich, C.T.: JAI Press. 
Dabholkar, P. A., \& Bagozzi, R. P. (2002). An attitudinal model of technology-based self-service: Moderating effects of consumer traits and situational factors. Journal of the Academy of Marketing Science, 30(3), 184-201.

Dabholkar, P. A., Bobbitt, L. M., \& Lee, E. J. (2003). Understanding consumer motivation and behavior related to self-scanning in retailing. International Journal of Service Industry Management, 14(1), 59-95.

Darian, J. C. (1987). In-home shopping: Are there consumer segments? Journal of Retailing, 63(2), 163-186.

De Burgos, J. (1999). An approach to integrating of environment as objective of the operations management (Una aproximación a la integración del medio ambiente como objetivo de la Dirección de Operaciones). Cuadernos de Economía y Dirección de la Empresa, 4, 259-83.

Eastlick, M. A. (1996). Consumer intention to adopt interactive teleshopping (pp. 96-113). Cambridge, M.A.: Marketing Science Institute.

Eiglier, P., \& Langeard, E. (1991). Servuction: Marketing of Services (Servuction: Le Marketing de Services). París: McGraw-Hill.

Ennew, C. T. (1996). Good and bad customers: The benefits of participating in the banking relationship. International Journal of Bank Marketing, 14(2), 5-13.

Fessard, J. L. (1993). The time of service (Le temps du service). France: Dunod.

Fischer, E., Gainer, B., \& Bristor, J. (1997). The sex of the service provider: Does it influence perceptions of service quality? Journal of Retailing, 73(3), 361-382.

Fisk, R. P., Brown, S. W., \& Bitner, M. J. (1993). Tracking the evolution of the services marketing literature. Journal of Retailing, 69(1), 61-103.

Friman, M., \& Gärling, T. (2001). Frequency of negative critical incidents and satisfaction with public transport services II. Journal of Retailing and Consumer Services, 8, 105-114.

Friman, M., Edvardsson, B., \& Gärling, T. (2001). Frequency of negative critical incidents and satisfaction with public transport services I. Journal of Retailing and Consumer Services, 8, 95-104.

Friman, M., Edvardsson, B., \& Gärling, T. (2003). A content analysis of complaints and compliments. Managing Service Quality, 13(1), 20-6.

Garvin, D. A. (1988). Competing on the eight dimensions of quality (Competir en las ocho dimensiones de la calidad). Harvard-Deusto Business Review, 34, 37-48.

Garvin, D. A. (1994). Strategic planning of production (Planificación estratégica de la producción). Harvard-Deusto Business Review, 59, 71-85.

Gerwin, D. (1987). An agenda for research on the flexibility of manufacturing processes. International Journal of Operations and Production Management, 7(1), 38-49.

Giardini, A., \& Frese, M. (2008). Linking service employees' emotional competence to customer satisfaction: A multilevel approach. Journal of Organizational Behavior, 29(2), 155-170.

Globerson, S., \& Maggard, M. J. (1991). A conceptual model of self-service. International Journal of Operations and Production Management, 11(4), 33-43.

Goodwin, C. (1996). Communality as a dimension of service relationships. Journal of Consumer Psychology, 5(4), $387-415$.

Goodwin, C., \& Gremler, D. D. (1996). Friendship over the counter: How social aspects of service encounters influence consumer service loyalty. In T. A. Swartz, D. E. Bowen, \& S. W. Brown (Eds.), Advances in services marketing and management (pp. 247-282). Greenwich, C.T.: JAI Press.

Graf, A. (2007). Changing roles of customers: Consequences for HRM. International Journal of Service Industry Management, 18(5), 491-509.

Greco, A. J., \& Fields, D. M. (1991). Profiling early triers of service innovations: A look at interaction home video ordering services. Journal of Services Marketing, 5(3), 19-26.

Gremler, D. D., Gwinner, K. P., \& Brown, S. W. (2001). Generating positive word-of-mouth communication through customer-employee relationships. International Journal of Service Industry Management, 12(1), 44-59.

Grove, S. J., \& Fisk, R. P. (1997). The impact of other customers on service experiences: A critical incident examination of “Getting Along”. Journal of Retailing, 73(1), 217-224.

Guenzi, P., \& Pelloni, O. (2004). The impact of interpersonal relationships on customer satisfaction and loyalty to the service provider. International Journal of Service Industry Management, 15(4), 365-384.

Gupta, M. C. (1995). Environmental management and its impact on the operations function. International Journal of Operations and Production Management, 15(8), 34-51. 
Gupta, M. C., \& Sharma, K. (1996). Environmental operations management: An opportunity for improvement. Production and Inventory Management Journal, 37(3), 40-46.

Gwinner, K. P., Gremler, D. D., \& Bitner, M. L. (1998). Relational benefits in services industries: The customer's perspective. Journal of Academy of Marketing Science, 26(2), 101-114.

Hair, J. F., Anderson, R. E., Tatham, R. L., \& Black, W. C. (1998). Multivariate data analysis. Englewood Cliffs, N.J.: Prentice Hall.

Hartline, M. D., \& Ferrell, O. C. (1996). The management of customer-contact service employees: An empirical investigation. Journal of Marketing, 60(10), 52-70.

Harvey, J., Lefebvre, L. A., \& Lefebvre, E. (1997). Flexibility and technology in services: A conceptual model. International Journal Operations \& Production Management, 17(1), 29-45.

Hee Yoon, M., Hyun Seo, J., \& Seog Yoon, T. (2004). Effects of contact employee supports on critical employee responses and customer service evaluation. Journal of Services Marketing, 18(5), 395-412.

Heskett, J. L. (1988). The management in service businesses (La gestión en las empresas de servicios). Barcelona, Spain: Plaza \& Janés Editores.

Hickson, D. J. (1966). A convergence in organization theory. Administrative Science Quartely, 11, 224-237.

Hsieh, A. T., Yen, C. H., \& Chin, K. C. (2004). Participative customer as partial employees and service provider workload. International Journal of Service Industry Management, 15(2), 187-199.

Huete, L. M., Roth, A. V., \& Vollmann, T. (1988). Delivery system industrialization strategies of American retail banks for 1990. Barcelona, Spain: Research Division-IESE.

Ivancevich, J. M., Lorenzi, P., Skinner, S. J., \& Crosby, P. B. (1996). Management: Quality and competitiveness. Irwin, London: McGraw-Hill.

Johnston, R. (1989). The customer as employee. International Journal of Operations and Production Management, 9(5), $15-23$.

Johnston, R. (1995). The determinants of service quality: Satisfiers and dissatisfiers. International Journal of Service Industry Management, 6(5), 53-71.

Johnston, R., \& Jones, P. (2004). Service productivity: Towards understanding the relationship between operational and customer productivity. International Journal of Productivity and Performance Management, 53(3), 201-213.

Kelogg, D. L., Youngahl, W. E., \& Bowen, D. E. (1997). On the relationship between customer participation and satisfaction: Two frameworks. International Journal of Service Industry Management, 8(3), 206-219.

Kim, J. S., \& Arnold, P. (1996). Operationalizing manufacturing strategy: An exploratory study of constructs and linkage. International Journal of Operations \& Production Management, 16(12), 45-73.

Klassen, K. J., \& Rohleder, T. R. (2002). Demand and capacity management decisions in services: How they impact on one another. International Journal of Operations and Production Management, 22(5), 527-548.

Langeard, E., Bateson, J., Lovelock, C. H., \& Eiglier, P. (1981). Services marketing: New insights from consumers and managers (pp. 81-104). Cambridge: Marketing Science Institute.

Lawrence, P., \& Karr, J. (1996). Technology spending and alliances: New highs in financial services firms. Journal of Retail Banking Services, 17(3), 45-52.

Leong, G. K., Snyder, D. L., \& Ward, P. T. (1990). Research in the process and content of manufacturing strategy. OMEGA International Journal of Management Science, 18(2), 109-122.

Lewis, B. R., \& Entwistle, T. W. (1990). Managing the service encounter: A focus on the employee. International Journal of Service Industry Management, 1(3), 41-52.

Lewis, M. A., \& Chambers, S. (1997). Implementing new technology in a service business. In J. Ribera, \& M. J. Prats (Eds.), Managing service operations: Lessons from the service and the manufacturing sectors (pp. 33-38), Barcelona: IESE, Canon Editorial.

Lovelock, C. H., \& Young, R. F. (1979). Look to customers to increase productivity. Harvard Business Review, 57(3), 168-178.

Maister, D. H. (1985). The one-firm firm: What makes it successful. Sloan Management Review, 27(1), 3-13.

Martin, C. L., \& Pranter, C. A. (1989). Compatibility management: Customer-to-customer relationships in service environments. Journal of Services Marketing, 3, 6-15.

Martin, C. R., Horne, D. A., \& Chan, W. S. (2001). A perspective on client productivity in business-to-business consulting services. International Journal of Service Industry Management, 12(2), 137-157.

Meuter, M. L., \& Bitner, M. J. (1998). Self-service technologies: Extending service frameworks and identifying issues for research. In D. Grewal, \& C. Pechmann (Eds.), Marketing theory and applications (pp. 12-19), Chicago: American Marketing Association. 
Meuter, M. L., Ostrom, A. L., Roundtree, R. I., \& Bitner, M. J. (2000). Self-service technologies: Understanding customer satisfaction with technology-based service encounters. Journal of Marketing, 64(7), 50-64.

Miller, J. G., \& Roth, A. V. (1994). A taxonomy of manufacturing strategies. Management Science, 40(3), 285-304.

Mills, P. K. (1986). Managing service industries. Cambridge, USA: Ballinger.

Mintzberg, H. (1993). Structure in fives: Designing effective organizations. Englewood Cliffs, N.J.: Prentice-Hall.

Mohr, L. A., \& Bitner, N. J. (1995). Process factors in service delivery: What employee effort means to customers. In T. A. Swartz, D. E. Bowen, \& S. W. Brown (Eds.), Advances in services marketing and management (pp. 91-117). Greenwich, C.T.: JAI Press.

Mulligan, P., \& Gordon, S. R. (2002). The impact of information technology on customer and supplier relationships in the financial services. International Journal of Service Industry Management, 13(1), 29-46.

Newman, W. R., \& Hanna, M. D. (1996). An empirical exploration of the relationship between manufacturing strategy and environmental management: two complementary models. International Journal of Operations and Production Management, 16(4), 69-87.

Normann, R. (1984). Service management: Strategy and leadership in service businesses. Chichester, England: John Wiley and Sons.

Parasuraman, A. (1996). Understanding and leveraging the role of customer service in external, interactive and internal marketing. Proceedings from Frontiers in Services Conference. Nashville, TN.

Parasuraman, A. (1998). Customers' comfort level with technology-based services: An empirical study. Proceedings from AMA Winter Educators' Conference. Austin, TX.

Price, L. L., Arnould, E. J., \& Deibler, S. L. (1995). Consumers' emotional responses to service encounters. International Journal of Service Industry Management, 6(3), 34-63.

Pujari, D. (2004). Self-service with a smile? Self-service technology (SST) encounters among Canadian business-to-business. International Journal of Service Industry Management, 15(2), 200-219.

Quinn, J. B. (1996). The productivity paradox is false: Information technology improves service performance. In T. A. Swartz, D. E. Bowen, \& S. W. Brown (Eds.), Advances in services marketing and management (pp. 71-84). Greenwich, C.T.: JAI Press.

Rafaeli, A. (1993). Dress and behaviour of customer contact employees: A framework for analysis. In T. A. Swartz, D. E. Bowen, \& S. W. Brown (Eds.), Advances in services marketing and management (pp. 175-211). Greenwich, C.T.: JAI Press.

Ramasubbu, N., Mithas, S., \& Krishnan, M. S. (2008). High tech, high touch: The effect of employee skills and customer heterogeneity on customer satisfaction with enterprise system support services. Decision Support Systems, 44(2), 509-523.

Raub, A. C. (1981). Correlates of computer anxiety in college students (Doctoral dissertation, Chemistry Department, University of Pennsylvania).

Rayport, J. F., \& Sviokla, J. J. (1995). Exploiting the virtual value chain. Harvard Business Review, 73, 14-24.

Rogers, J. D., Clow, K. E., \& Kash, T. J. (1994). Increasing job satisfaction of service personnel. Journal of Services Marketing, $8(1), 14-26$.

Sasser, W. E., Olsen, R. P., \& Wyckoff, D. D. (1982). Management of service operations. Boston: Allyn and Bacon.

Schlessinger, L. A., \& Heskett, J. L. (1991). The service-driven service company. Harvard Business Review, 69(5), 71-81.

Schneider, B., \& Bowen, D. E. (1985). Employee and customer perceptions of service in bands: Replication and extension. Journal of Applied Psychology, 70, 423-433.

Schneider, B., \& Bowen, D. E. (1995). Winning the service game. Boston: Harvard Business School Press.

Shaw, J. C., \& Capoor, R. (1979). Quality and productivity: Mutually exclusive or interdependent in service organizations? Management Review, 3, 25-39.

Skinner, W. (1969). Manufacturing missing link in corporate strategy. Harvard Business Review, 47, 136-145.

Slack, N., Chambers, S., Johnston, R., Harland, C., \& Harrison, A. (1994). Operations management. Pitman.

Snellman, K., \& Vihtkai, T. (2003). Customer complaining behaviour in technology-based service encounters. International Journal of Service Industry Management, 14(2), 217-231.

Solomon, M. R., Surprenant, C., Czpiel, J. A., \& Gutman, E. G. (1985). A role theory perspective on dynamic interactions: The service encounter. Journal of Marketing, 49, 99-111.

Specht, N., Fichtel, S., \& Meyer, A. (2007). Perception and attribution of employees' effort and abilities: The impact on customer encounter satisfaction. International Journal of Service Industry Management, 18(5), 534-554.

Surprenant, C. F., \& Solomon, M. R. (1987). Predictability and personalization in the service encounter. Journal of Marketing, 51(4), 73-80. 
Tansik, D. A. (1990). Managing human resource issues for high-contact service personnel. In D. E. Bowen, R. B. Chase, \& T. G. Cummings (Eds.), Service management effectiveness: Balancing strategy, organization and human resources, operations, and marketing (pp. 152-176). Unites States: Jossey-Bass Publishers.

Tat Keh, H., \& Wei Teo, C. (2001). Retail customers as partial employees in service provision: A conceptual framework. International Journal of Retail and Distribution Management, 29(8), 370-378.

Toffler, A. (1980). The third wave. London: Collins.

Voss, C. A., Armistead, C. G., Johnston, R., \& Morris, B. (1985). Operations management in service industries and the public sector. Chichester: Wiley.

Walker, R. H., Craig-Lees, M., Hecker, R., \& Francis, H. (2002). Technology-enabled service delivery: An investigation of reasons affecting customer adoption and rejection. International Journal of Service Industry Management, 13(1), 91-110.

Ward, P. C., McCreery, T. K., Ritzman, L. P., \& Sharma, D. (1998). Competitive priorities in operation management. Decision Sciences, 29(4), 1035-1046.

Willmott, H. C. (1981). The structuring of organizational structures: A note. Administrative Science Quarterly, 26, 470-474.

Zeithaml, V., \& Gilly, C. (1987). Characteristics affecting the acceptance of retailing technologies: A comparison of elderly and nonelderly consumers. Journal of Retailing, 63(1), 49-68. 